\title{
Chapter 8 \\ Access to Social Protection by Immigrants, Emigrants and Resident Nationals in India
}

\author{
Sony Pellissery, Saloni Jain, and Geo Varghese
}

\subsection{Overview of the National Social Security System and Key Migration Features in India}

\subsubsection{Main Characteristics of the National Social Security System}

Just like other countries in the Global South, India has put forward a social security system that is largely influenced by its colonial legacy. Many 'welfare' concerns were operationalized through the framework of developmental state (Pellissery and Sasidhar 2018) that aimed to modernize the nation through a process of state-led economic growth. Yet, following the colonial legacy, those close to the state ('formal' workers) received social security arrangements comparable to those in advanced industrialised welfare states.

Welfare arrangements in India have a segmented nature. This country has one of the largest informal economies in place (Pellissery 2013). About 92\% of the Indian labour force is working in unorganised sector without access to any formal social security mechanisms (NCEUS 2007). Those who are in the formal sector are provided with social security measures, thus being considered as a privileged segment of the Indian society. Most international workers (except undocumented migrants) work in the formal sector and are considered to be part of the formal labour market.

\footnotetext{
S. Pellissery $(\square)$

Institute of Public Policy, National Law School of India University, Bangalore, India

S. Jain

Centre for Energy Finance, Council on Energy, Environment and Water (CEEW),

New Delhi, India

G. Varghese

Department of Political Science, St Joseph's College of Law, Bengaluru, India
} 
The segmented labour market is reinforced by social security arrangements and labour laws largely influenced by India's colonial past. Employee's State Insurance Act (1948, ESI) is modelled after the British welfare arrangements for industrial workers and is currently the overarching framework for social security in India.

Social welfare is a subject placed among the 'directive principles' of the Indian Constitution, resulting in the state's engagement in social security as a desirable activity, rather than an obligatory sector of intervention. Constitutional articles 38, 41, 42 and 47 dealing with social welfare were placed in the 'concurrent list' where there is joint responsibility between regional/local states and central government. This categorisation of social policies as a 'desirable activity' led to a "needs-based conception of justice in theory, but was in practice based on ideas of charity, benevolence and paternalism. The idea of a right to welfare or justice was clearly precluded" (Jayal 2011: 39). Therefore, appeasing the electorate was at the heart of the development of the Indian social security system in federal states (Pellissery and Barrientos 2013). For instance, until 1995, there was no national level noncontributory pension system. Yet, most regional states were providing pensions from their local budgets.

Because of the segmented nature of the labour market and the fact that the majority of workers are engaged in the informal economy, labour laws cover only to a small proportion of the work force. The main social security instrument for workers - the Employee's Provident Fund Organization (EPFO) - is applicable only to about $12 \%$ of the population (CSO 2018). ${ }^{1}$ Most labour laws applicable to private companies (where migrants are largely employed) are within the purview of the federal state. Therefore, there is a significant variation between Indian states on labour regimes. Such a scenario, coupled with heightened globalization, has resulted in approaching labour through the logic of economic production. A recent review of the legislation in the post-liberalised India (Pellissery 2008) has shown that court interpretations of the law have favoured employers.

This segmented labour market has created a limited possibility for the application of human rights. The International Convention of Economic, Social and Cultural Rights (ICESCR) ${ }^{2}$ states that the right to social security implies two predominant categories of measures: social insurance schemes (contribution based) and social assistance schemes (non-contributory and typically taxation-funded measures through means-tested mechanisms for the vulnerable population). Although India is signatory of this declaration, the Constitution of India does not recognize

\footnotetext{
${ }^{1}$ This low level of take up is primarily since these laws are applicable in establishments, which has more than 20 workers. In the informal economy, employers, in order to avoid payment of social security benefits, arrange their production units in such a way that in a legal unit, there will be less than 20 workers.

${ }^{2}$ Also in Universal Declaration of Human Rights (UDHR), Articles 22 and 25; CeRD, Article 11; CRC, Article 26; and the Convention for the Protection of Migrant Workers and their Families (CMW), Article 27. it also appears in regional human rights instruments (Protocol of San Salvador, Article 9;, European Social Charter, Article 12), and in several Conventions of the international Labour Organisation (ILO), in particular Convention No. 102 on Minimum Standards of Social Security. The CRPD explicitly refers to the right to social protection (Article 28).
} 
social security as a fundamental right. However, Article 41 of the Constitution does stipulate that the state should - within the limits of its economic capacity- secure the right to work, education and public assistance in case of unemployment, old age, sickness and disability. Article 42 further requires the state to secure just and humane working conditions and maternity relief. Article 47 also stipulates that the state should raise the level of nutrition and the standard of living and improve the public health sector. These obligations require the state to create a broader outline of a social security regime.

In practice, India's social security schemes cover only a very small segment of the organised work force. Out of an estimated work force of around 397 million, only 28 million benefit from formal social security protection (Pellissery et al. 2014). Although $90 \%$ of the workforce is working in the unorganized sector according (Asian Development Bank 2016), the total social protection expenditure in India as a percentage of the GDP in 2012 was 1.6 (compared to 6.5 in China, 4.4 in Thailand, and 2.6 in Sri Lanka during the same period). In other words, social expenditure is primarily an out-of-pocket expenditure for most Indian families.

Since 1991, India formally entered the globalized economy by accepting the terms and conditions for loan from the International Monetary Fund. This has resulted in several layers of economic reforms. Apart from an open economy (ending the protected economy), state's intervention in several key social sectors have been re-oriented. Consequently, private actors have been allowed to intervene in areas such as education, health, and pensions. As the labour market also saw a new category of 'international workers' in skilled jobs, ESI has been recently modified in order to incorporate their concerns, as explained in the next section.

\subsubsection{Migration History and Key Policy Developments}

The rich resources and geographical positioning of India has significantly contributed to the migration inflows towards this country. The size of the country itself has generated large stocks of internal migrants generally moving between different places within the same regional state. It is estimated that around $35 \%$ of people in urban areas and $26 \%$ of residents of rural areas have moved from their place of usual residence (Census of India 2011). According to the national Census data, the total number of internal migrants increased significantly during the past decades, from 167 million individuals in 1971 to 315 million in 2001. The National Sample Survey revealed that in 2008, about $28.5 \%$ of Indians (over 325 million people of the total population of 1.14 billion) were internal migrants. Internal migration has thus become an important issue from the perspective of social security. Although this specific type of migration is beyond the aim of this chapter, some of the social security provisions discussed here do include the eligibility condition of local residence, thus excluding internal migrants from social security provisions. 
Determining who is an immigrant and who is a citizen is a rather complicated task in some parts of India, especially in the border regions. In some places (for instance, the North East of India) citizenship debates are contentious, and civil rights are denied for generations, let alone social rights. There is a recent attempt to create a National Register of Citizens according to which those whose names are in the official list until 1971 will be considered as citizens. There are various issues of documentary proofs. Since 2009, the Indian government has attempted to issue a unique identification document (aadhar card). Until July 2018, 1.22 billion identification cards have been issued (UIDAI 2018), although problems still remain for individuals who might be missed out of such registration processes.

In 2006, foreigners accounted for $0.4 \%$ of India's total population - approximately 5 million people (World Bank 2008), with most of them originating from neighboring countries such as Bangladesh, Pakistan, Afghanistan, Bhutan, Sri Lanka, Nepal, Myanmar or China. ${ }^{3}$ The emigrant population represents about $0.9 \%$ of the total population (above 10 million people). ${ }^{4}$ Most of them come from few states (Kerala, Tamilnadu, Goa, Punjab, Gujarat, Andhra Pradesh) and they generally respond to two different migration trajectories: either skilled workers who migrated to the UK, USA, Australia, Canada and other developed countries since the 1950s or low-skilled emigrants who have started to move to Middle East or South East countries on temporary labour contracts since 1970s (Rajan 2010). ${ }^{5}$ As explained below, these two categories respond to quite different social security requirements.

'Foreigners' broadly fall into the two categories mentioned in the previous paragraph. Unskilled foreign workers are typically from neighbouring states (rarely from other middle and low developed economies), and they compete for social security resources with large number of Indian unskilled labourers. Therefore, for political reasons, Indian low skilled labourer are preferred over foreigners. On the other hand, when it comes to skilled migrant labourers, they are typically well-off than majority of Indian population. They have access to private social security

\footnotetext{
${ }^{3} \mathrm{~A}$ significant portion of migration from neighbouring countries, particularly from Bangladesh, is sensitive political issue of illegal immigration. Very often this has resulted in communal riots between migrants (primarily Muslims) and local residents (primarily Hindus). The Illegal Migrants (Determination by Tribunal) (IMDT) Act, enacted in 1983 was later struck down by the Supreme Court of India in 2005.

${ }^{4}$ Sources based on Indian data (NSSO 2008) suggest there are around four million Indian citizens residing abroad. However, the sending country statistics are often unable to capture families that have migrated with the migrant. The figure of 10 million is based on the World Bank's assessment. The India Migration Report (2010) estimates six million Indian emigrants working in Gulf countries alone. The World Bank estimates that US \$ 55,000 million was received as remittance in 2010 alone. Compared to this, outward remittance flow was as small as US \$ 4000 million. International Organisation for Migration predicts that India will emerge the largest migrant-sending country globally by 2050 .

${ }^{5}$ It is estimated that $90 \%$ of migrants of the state of Kerala are living and working in the Gulf countries.
} 
arrangements, and therefore do not make a political demand for the same. ${ }^{6}$ Exceptions to this large apathy towards 'foreigners' is where India has signed SSAs and 'international workers' are recognised.

\subsection{Migration and Social Protection in India}

This section will examine how social protection is being provided in life circumstances of unemployment, sickness, old age, difficult family circumstances and income loss. In particular, we will examine how social protection is being extended to domestic citizens and foreigners. As indicated in the previous sections of this chapter, in a segmented economy - formal and informal workers - social protection benefits are also extended in segmented manner. Foreign workers, primarily being in the private sector, are treated to cover the social protection benefits through private sources. However, in recent times, recognition of 'international worker' has begun to recognise foreigners eligible for certain social protection benefits.

\subsubsection{Unemployment}

In an informal economy, it is extremely hard to calculate who is employed and who is not. The share of people engaged in several gainful activities though the salaried jobs have decreased. ${ }^{7}$ The Centre for the Monitoring of the Indian Economy (CMIE) estimated that around 31 million persons were seeking for a job in India in February 2018 (6.5\% unemployment rate).

Three main schemes aim to address unemployment in India. Under the National Employment Scheme, some regional governments provide unemployment allowances to specific categories of jobseekers out of their own resources through employment exchanges. ${ }^{8}$ The national level Unemployment Allowance Scheme (Rajiv Gandhi Shramik Kalyan Yojna) was introduced in 2005 as an unemployment insurance programme managed by Employees' State Insurance Corporation (ESIC). The eligibility condition for Rajiv Gandhi Shramik Kalyan Yojna are: (a) the person

\footnotetext{
${ }^{6}$ It is interesting to note that travel concession (train), seen as a civil right than social right, used to be provided to all senior citizens above the age of 60 until 2016. Since then this facility for foreigners is taken away and only nationals are entitled for $50 \%$ of travel concession.

${ }^{7}$ In economic theory, the complexity of 'disguised unemployment' explains this phenomenon. Yet, as per the report of National Skill Development Mission, 97\% of Indian workforce has not undergone any skill training.

${ }^{8}$ But the Committee (Forty-second Report of the Standing Committee on 'The Employment Exchanges (Compulsory Notification of Vacancies) Amendment Bill, 2013) observe that the Employment Exchanges have lost their significance due to changing trends for e.g. rise in number of contract workers, use of capital intensive techniques, technological developments, outsourcing and emergence of recruitment boards have led to reduced coverage under the Act.
} 
should have been an insured person (IP) under the ESI Act on the date of loss of insurable employment, on account of closure of the factory or establishment, retrenchment, or permanent invalidity arising out of non-employment injury; (b) the insured person should have contributed under the ESI Scheme for at least two years; (c) applications for Unemployment Allowance should be within six months from the date of loss of employment; and (d) minimum 1 month waiting period after unemployment is needed. However, this scheme has a very low take up, ${ }^{9}$ mainly due to the fact that it applies to factories having at least 10 workers or similar organizations with at least 20 workers. Furthermore, only national residents can apply for this scheme as foreigners and non-resident nationals do not qualify as eligible applicants.

India also provides an unemployment assistance scheme in the form of the National Employment Guarantee Act. 100 days of wage employment are guaranteed in a financial year to every rural household whose adult members volunteer to do unskilled manual work. ${ }^{10}$ National citizens residing in the country are not required to have exhausted ${ }^{11}$ the right to unemployment insurance (RGSKY) benefits to become eligible to claim unemployment assistance under MGNREGS. However, the benefit is only for 'local residents' (this refers to village domicile which is the lowest tier of governance where the demand for job is made) as applicants must prove residence in the village. All adult members of the household who register may apply for work. To register, they have to: (a) be local residents ('local' implies residing within the Gram Panchayat, ${ }^{12}$ including those that may have migrated some time ago but may return); (b) be willing to do unskilled manual work; and (c) apply as a household (nuclear or single-member family) at the local Gram Panchayat. The Act is not specific about whether foreign residents are eligible for employment guarantee even if they stay in the village.

The third scheme- Swarna Jayanti Shahari Rozgar Yojana- was introduced in 2012 in order to provide gainful employment to the urban unemployed and under employed poor, by encouraging the setup of self-employment ventures by the urban poor living below the poverty line, skills training and also through providing wage

\footnotetext{
${ }^{9}$ In 2009 a reported number of 3881 were assisted through this scheme.

${ }^{10}$ Ref. http://nrega.nic.in/netnrega/writereaddata/Circulars/2342AP_drought_letter_6_June_18. pdf (Accessed on 03 November 2018).

${ }^{11}$ Theoretically speaking, the Employment Guarantee scheme is in parallel to unemployment insurance benefit. In practice, both are addressed at two separate segments. Employment guarantee scheme is targeted at rural unskilled workers ready to engage in manual labour, whereas unemployment insurance is targeted towards skilled graduates (generally in urban areas) who are registered for a job.

${ }^{12} \mathrm{Gram}$ Panchayat is the lowest tier of governance in India. It is often translated as village. The size and geographical area differs from region to region. However, there is a constitutionally mandated elected body and bureaucracy at this lower tier. For various schemes, this lowest tier is devolved the responsibility to verify the eligibility conditions for welfare assistance. The expression of 'local domicile' typically refers to Gram Panchayat certifying the person concerned regularly residing in the village.
} 
employment by utilizing their labour for construction of socially and economically useful public assets. The scheme is categorical in nature.

\subsubsection{Health Care}

India has one of the lowest health expenditure as share of GDP in the world (1.4\%). It has a thriving private health care market and poor quality public health system. Most residents do not have access to any insurance system, and about $70 \%$ of health expenses represent out-of-pocket expenditure.

The health care system is segmented in two ways. First, only those who have a formal employment can enjoy free medical treatment through the chain of hospitals run by Employees' State Insurance Corporation (ESIC). ${ }^{13}$ Currently, the ESI Scheme is not applicable to foreigners or citizens residing abroad. National citizens residing abroad can claim invalidity benefits under the Pravasi Bharatiya Bima Yojana (more details below) and not under the ESIC scheme. However, this covers only a limited segment of the population- less than $2 \%$ in 2017 . The second type of segmentation derives from the access the insurance. The rich segments of the population have access to an insurance that covers medical procedures in advanced hospitals. To address this second type of segmentation, the scheme Rashtriya Swasthya Bima Yojana (RSBY) was launched in 2008 to cover Below Poverty Line families. The scheme is jointly funded by the central government and the state government and aims to reduce out of pocket expenditure on health, while also increasing access to health care. The eligibility condition for RSBY is belonging to the section of nationally defined below poverty line. This is determined by state governments. Most of the state governments consider citizenship as criteria for BPL, ${ }^{14}$ thus, excluding foreigners. Recently, some sections of labourers are also brought eligible for RSBY, including building and other construction workers registered with the Welfare Boards, licensed railway porters, street vendors, MNREGA workers who have worked for more than 15 days during the preceding financial year, Beedi workers, domestic workers, sanitation workers, mine workers, rickshaw pullers, rag pickers, and auto/taxi drivers. ${ }^{15}$

The Pravasi Bharatiya Bima Yojana (PBBY) is a mandatory insurance scheme initiated in 2003 with the aim of safeguarding the interests of Indian emigrant workers, both working for Indian companies and companies owned by foreigners in a different country. The insured workers are covered for accidental death or permanent disability leading to loss of employment while abroad. The insurance also compensates for the costs of hospitalization. Coverage of repatriation for medically

\footnotetext{
${ }^{13}$ Ref. https://www.esic.nic.in/sickness-benefits (accessed on 02 October 2018).

${ }^{14}$ Ref. https://archive.india.gov.in/howdo/howdoi.php?service=7 (accessed on 12 December 2018).

${ }^{15}$ Ref. https://www.india.gov.in/spotlight/rashtriya-swasthya-bima-yojana\#trsby3 (accessed on 11 December 2018).
} 
unfit/premature termination of employment, maternity expenses benefit to female emigrants and legal expenses related to emigrants' overseas employment are some of the benefits covered through this scheme (MEA 2017).

The public health centres, where primary services are provided don't distinguish between citizens and foreigners. Yet, the standards of their services are poor and often people self-select to receive services if the care could be affordable from private sources. However, in the public health system itself, secondary and tertiary services are of higher quality. Yet, most of these services are on payment basis.

\subsubsection{Pensions}

India's pension system is also highly segmented. The vast majority of the population do not have any arrangements for an old-age pension. The law requires children to care their parents, such care being provided without legal sanctions in a traditional joint family system. Only a small share of the population (less than 7\%) that is in the formal sector enjoys the state pension.

Since 2004, this state-funded pension system was turned into a contribution based system through the National Pension Scheme. This is available to any citizen of India, whether resident or non-resident, therefore excluding foreign residents. Claimants must be aged between $18-60$ years. After attaining 60 years of age, individuals will not be permitted to make further contributions to the NPS accounts. NPS account can be operated from anywhere in the country irrespective of individual employment and location/geography. An individual is eligible for withdrawal before the tenure only if he/she has contributed for at least 10 years in the NPS Account. Further, one must contribute at least Rs. 6000 for tier 1 account and Rs. 2000 for tier 2 account annually for 10 years to avail the benefits of pre-mature or mature withdrawal. Since 1991, private companies have been allowed to operate in the pension sector. Since 2009, the National Pension Scheme is open to all citizens for contribution-linked pension system. Yet, until December 2017, less than $1 \%$ of population is part of this pension system. In other words, access to these private pension funds are hugely dependent on income, and therefore limited.

Contribution-linked National Pension Scheme is open to all citizens of India. While employers have the provision to make contributions to supplement that of employees, the Government of India does not make any contributions towards this scheme. Both residents and non-residents could be part of this scheme. There is also a minimum contribution clause of Rs. 2000 per annum to remain in the National Pension Scheme.

Only international workers working under an employment visa are subject to the regulations of EPF, and contractual work or short-term business travel is exempt. However, there are certain exemptions regulated via bilateral arrangements when international workers contribute to their home country social security system or when they have the 'detached worker' status as specified in the social security agreement. Furthermore, economic agreement exemptions are granted when: (a) 
international workers contribute to the home country system; (b) the participation in India's social security system is specifically exempted by the economic agreement and; (c) only those employees covered by a bilateral agreement are eligible for withdrawal benefit under the EPF, 1995, who have not rendered the eligible service (i.e. 10 years) even after including the totalisation benefit as may be provided in the said agreement. In all other cases, withdrawal benefit under the EPS, 1995 will not be available to international workers for contributory service less than 10 years.

India also provides a non-contributory pension scheme- the National Old-age Pension Programme designed for citizens who are below poverty line. Only those who do not qualify for a contributory pension are eligible to apply for this noncontributory pension scheme. However, the pension amount is very small (Rs. 200 per month, although most regional governments complement this with additional funds). This non-contributory pension is means-tested and granted a person who is 60 years or above and belongs to a household below the poverty line. The period of prior residence is not an eligibility criterion under the scheme. However, the scheme is reserved only for resident citizens as resident foreigners or non-resident citizens cannot apply for it.

\subsubsection{Family Benefits}

In several ways, family as an institution is central to the Indian society and culture. Therefore, several life-contingencies are taken care by the family as a unit. For workers in the formal sector, though there are maternity and paternity leaves (the latter only for some specific categories of workers), there is no system of parental benefits or child benefits in the Indian social security system. Maternity benefits are paid for 12 weeks, although mothers have 26 weeks of maternity leave. Since maternity benefits are granted to employees covered by the ESI Act, they also cover 'international workers'. Hence, foreign residents can access maternity benefits from India under the same conditions as national residents.

One major challenge in India is providing support for women who are in the informal sector. Neo-natal and maternal deaths are extremely high in India. Since 2005, a safe motherhood programme was introduced (Janani Suraksha Yojana, JSY) as a targeted scheme for all pregnant women below the poverty line. The scheme is financed by the central government and provides cash assistance, nutrition and routine physical examination for mothers. As previously mentioned, India does not have a child benefit scheme. Yet, since 1975, the Integrated Child Development Scheme provides nutrition, health check-up, education, and child care until the age of six when children are compulsorily required to be enrolled in a school. Around 13,30,000 anganwadi (community based shelters) across the country provide these services in kind. Several state governments have extended the services in these centres to international migrants. However, several study reports (PEO 2011) have shown that self-exclusion is the mechanism in these places. 


\subsubsection{Guaranteed Minimum Resources}

There is no non-categorical, non-contributory scheme of guaranteed minimum resources in India. However, there are certain schemes that do provide benefits in cash to individuals in need. One example is the employment guarantee scheme initiated in 2005 that provides 100 days wage employment for rural areas to every household whose adult members volunteer to do unskilled manual work. $69 \%$ of the Indian population live in rural areas (Census 2011), hence this scheme covers most of the population. A condition of local citizenship (village domicile) prevents migrants from accessing this scheme. Secondly, the National Social Assistance Programme (NSAP) introduced in 1995 provides support to certain groups of individuals (aged persons, widows, disabled persons, bereaved families on death of primary bread winner) living in households below the poverty line. These are noncontributory benefits accessible only to resident citizens. Since the administration of these schemes is done through local governments, internal migrants are not eligible since they have to provide a resident certificate of five years. Last but not least, the Unorganised Sector Workers' Social Security Scheme which came into force since 2004 is contributory in nature. There have been discussions on universal basic income (Economic Survey 2016), although there are no current plans for its implementation.

\subsubsection{Bilateral/Multilateral Social Security Agreements}

As previously mentioned, the category of 'international worker' introduced in 2008 is particularly relevant when discussing migrants' access to social protection in India. An international worker is defined as: a) any Indian employee working or having worked abroad in a country with which India has entered into a Social Security Agreement (SSA) or; b) any foreigner working in India in an establishment where the Employees "Provident Funds \& Miscellaneous Provisions Act, 1952 is applicable. Generally, this refers to any registered work place with more than 10 workers.

International workers are eligible for the benefits covered by the Employees' Provident Funds and Miscellaneous Provisions Act, 1952. These are contributory benefits through Employees Provident Funds Scheme (1952), Employees' Pension Scheme (1995) and Employees Deposit Linked Insurance Scheme (1976). International Workers contributing to the social security of their country of origin, with which India has entered into a Social Security Agreement and enjoying the status of a detached worker are considered to be excluded.

India currently has bilateral social security agreements with 19 countries: Belgium, Germany, Switzerland, Luxembourg, France, Denmark, Republic of Korea, Netherlands, Hungary, Sweden, Finland, Czech Republic, Austria, Norway, Australia, Canada, Japan, and Portugal. Most of these agreements were signed with 
are EU member states, It is important to note none of these countries are neither on the list of top three destination countries for Indian migrants, nor the workers from these countries form highest number of foreigners residing in India. Partly in response to the demands of companies with business in both these countries to facilitate movement of their employees. For each country, the social benefits covered in the agreements are different. For instance, the agreement with Canada covers old-age and survivors' pension for employed persons and the Permanent Total Disability pension for employed persons. Similarly, for those coming from Singapore are exempted for Provident Fund contributions since India has a Comprehensive Economic Partnership Agreement with Singapore.

In terms of international cooperation in the field of social security, it is also worth mentioning that India is member of the Colombo Process, a regional consultative process on management of overseas employment and contractual labour for countries of origin in Asia. ${ }^{16}$ The main aim of the Colombo Process is to provide a forum for Asian Labour sending countries to discuss and resolve issues pertaining social security. Among this, with some of the Gulf Region Countries (where 6 million Indians work) there have been bilateral agreements signed since 2004. These countries are Kuwait, Oman, Malaysia, Bahrain, Yemen, Jordan and Qatar. The Indian Ministry of External Affairs has set up several offices in Gulf countries as part of India Centre for Migration for various helps. ${ }^{17}$ What is important to remember is these agreements primarily facilitate smoothening of a range of civil issues since recruitment in host countries through unscrupulous private agencies create a range of problems for illiterate and low skilled workers.

\subsubsection{Obstacles and Sanctions}

There are several obstacles and sanctions for foreigners or citizens residing abroad in accessing social benefits across the five core policy areas analyzed in this chapter. In the case of unemployment schemes (Rajiv Gandhi Shramik Kalyan Yojana and Mahatma Gandhi National Rural Employment Scheme), our findings indicate that while there are no migration related restrictions per se, citizens living abroad may be able to access these schemes only if they are insured under the ESI Act and have contributed for a minimum period of five years prior to loss of employment. ${ }^{18}$ Similarly, there are no restrictions on foreigners living in India to avail the scheme provided they qualify as employees under Section 2(9) of ESI Act and fulfil the

\footnotetext{
${ }^{16}$ The eleven member countries for the process are Afghanistan, Bangladesh, China, India, Indonesia, Nepal, Pakistan, the Philippines, Sri Lanka, Thailand and Vietnam and eight destination country participants are Bahrain, Italy, Kuwait, Malaysia, Qatar, Republic of Korea, Saudi Arabia and the United Arab Emirates.

${ }^{17}$ Utilisation of Welfare fund established by this Centre shows about $50 \%$ of money is spent on supporting people with air travel.

${ }^{18}$ Circular, No. N-11/12/2003-Bft.II/Vol.II,Rajiv Gandhi Shramik Kalyan Yojana.
} 
above mentioned criteria. However, needless to say, the scheme is valid only for the companies which are covered under the ESI Act. In the case of MGNREGS, citizens residing abroad may not be able to access the benefits of the scheme as it is applicable to only those "rural household whose adult members volunteer to do unskilled manual work" 19 assigned within the country. As far as the liberal interpretation of the law is concerned, foreigners living in India may be able to access the benefits of the scheme provided their household is registered by the Gram Panchayat. However, in reality, this process is bound to be filled with obstacles as the registration process is left to the whims and fancies of the Gram Panchayat.

To avail the social security benefits in the domain of health care mainly covered by the integrated need based social insurance scheme provided by the ESI Act, 1948, there are no migration related obstacles for foreigners or nationals. In Rashtriya Swasthya Bima Yojana, we find that there is a major obstacle for foreigners in availing the scheme as the programme is applicable only to the BPL category household or specified unorganised sector workers and therefore applicable only to Indian citizens. For citizens who are eligible for the scheme but are living abroad, the major obstacle arises in using the benefits of the scheme which is applicable only in hospitals across India.

There are two schemes that cover the maternity benefits in the area of family benefits. The Maternity Benefits Act (1961) does not impose any migration related constraints for non-national residents or non-resident nationals to access this scheme. The Act only require female employees to have worked for at least 80 days during the year immediately preceding the expected delivery date in order to be eligible to claim the benefit. ${ }^{20}$ Similar is the case with the maternity benefits under the ESI Act (1948) which are available to insured employees (women), "earning wages up to INR 21,000 and who have contributed for a period of at least 70 days in the immediately preceding two consecutive contribution periods". ${ }^{21}$ However, the women employees covered under the ESI Act may not be able to access the benefits of the Maternity Benefits Act.

Lastly, in the area of pensions, the contributory pension schemes namely National Pension Scheme and Atal Pension Yojana, we find that APY is applicable only to citizens and therefore citizens living abroad can access the scheme, provided that person is not a non-resident Indian (NRI). On the other hand, any citizen of India can access the National Pension Scheme, independently of his/her place of residence. In the case of Employee pension scheme covered under the Employees' Provident Funds and Miscellaneous Provisions Act, 1952 there are no migration related restrictions on citizens or foreigners living abroad to avail the scheme provided the employees are members of the Employee Provident Fund Scheme. In the non-contributory pension scheme, the applicant must necessarily belong to a household living below poverty line. Citizens living abroad may be able to access the

\footnotetext{
${ }^{19}$ Sec 3(1), National Rural Employment Guarantee Act, 2005.

${ }^{20}$ Sec 5(2), Maternity Benefit Act, 1961.

${ }^{21}$ Sec 50, ESI Act, 1948.
} 
scheme provided the "applicant is a destitute, having no regular source of financial support from family members or any other sources." 22

In general, we can conclude that all labour laws regulating employment relationships in India also apply to foreign nationals employed in India. In our research, we find no evidence of sanctions against foreigners and accessing certain benefits in the policy areas mentioned above do not constrain their access to residence permit, family reunification or nationality in India.

\subsection{Conclusions}

As we have shown, welfare state is not a home-grown idea to India, as common with several countries in Global South, where industrialisation has not prompted the state intervention for de-commodification. In predominantly agrarian and service-led economies, social security is perceived as a subject that is relevant for a small section of the society. In India's segmented economy, this has particularly favoured a miniscule section of formal sector workers who are seen as elite section of the society. In the large segment of informal workers, there is significant immigrant population from neighbouring countries. However, for this immigrant population often civil rights are not also provided, let alone social rights (Pellissery et al. 2014. Their civil status is a matter of political contention. Since 2009, the Indian government has attempted to issue a unique identification document (aadhar card), which has 1.22 billion card holders as of July 2018.

Since the opening up of the Indian economy to foreign capital and foreign workers in skilled sector, several changes have taken place. India's architecture of Employee State Insurance Act (1948) was amended in 2008 in order to include a new section on 'International Workers'. However, stringent conditionalities are introduced to give them social rights, as discussed in this chapter. These conditionalities have a logic that formal workers (typically international workers) are far better off than informal workers (which form the large voter base) who are the primary target of Indian welfare state.

Another major development is the ongoing process of signing totalisation agreements with countries where skilled labourers are travelling from India. So far, 19 countries (primarily from the European Union) have signed such totalisation agreements for transferrable social security arrangements. India also has bilateral agreements with six countries in Gulf Region where six million Indians are working. In several regions, this diaspora forms a significant voice and shapes political discourses, which in turn incentivises the ruling parties to create favourable working conditions for such population.

${ }^{22}$ National Social Assistance Programme (NSAP), 1995. 
Acknowledgements This chapter is part of the project "Migration and Transnational Social Protection in (Post)Crisis Europe (MiTSoPro)" that has received funding from the European Research Council (ERC) under the European Union's Horizon 2020 research and innovation programme (Grant agreement No. 680014). In addition to this chapter, readers can find a series of indicators comparing national social protection and diaspora policies across 40 countries on the following website: http://labos.ulg.ac.be/socialprotection/.

\section{References}

Asian Development Bank. (2016). The social protection indicator. Manila: Asian Development Bank.

Census of India. (2011). Census of India- 2011. New Delhi: Government of India.

Central Statistical Organisation. (2018). Economic census of the Ministry of Statistics. New Delhi: Government of India.

Economic Survey. (2016). Universal basic income. In Economic survey. New Delhi: Government of India.

India Migration Report. (2010). Governance and Labour Migration. New Delhi: Routledge.

Jayal, N. G. (2011). A false dichotomy? The Unresolved tension between the Universal and Differentiated citizenship in India. Oxford Development Studies, 39(2), 185-204.

Ministry of External Affairs. (2017). Welfare and protection of Indians abroad. https://www.mea. gov.in. Accessed 1 Sept 2018.

National Commission on Enterprises in Unorganised Sector. (2007). Report on the conditions of work and promotion of livelihood in the unorganized sector. New Delhi: Government of India.

NSSO. (2008). Employment-Unemployment and Migration: 64th Round of National Sample Survey. New Delhi: Ministry of Statistics and Programme Implementation.

Pellissery, S. (2008). Reforms in Indian Labour Market in the post-liberalization period. http:// papers.ssrn.com/sol3/papers.cfm?abstract_id=2260745

Pellissery, S. (2013). Informal economy: Dilemmas and policy responses. In R. Surender \& R. Walker (Eds.), Social policy in a developing world (pp. 115-127). London: Edward and Elgar.

Pellissery, S., \& Barrientos, A. (2013). Expansion of social assistance: Does politics matter? Economic \& Political Weekly, 48(9), 47-54.

Pellissery, S., \& Sasidhar, T. V. S. (2018). India as post-colonial welfare state. In B. Greve (Ed.), Routledge handbook of welfare state. London: Routledge.

Pellissery, S., Biswas, S., \& Sengupta, M. (2014). Social security for migrants in a segmented economy: The case of India. In P. A. Ortiz et al. (Eds.), Social security and migrant workers (pp. 153-166). Amsterdam: Woulters Kluwer.

Programme and Evaluation Organisation. (2011). An evaluation study of Integrated Child Development Scheme. New Delhi: Planning Commission.

Rajan, I. (2010). India migration report: Governance and labour migration (Vol. 1). New Delhi: Routledge India.

World Bank. (2008). Migration and Remittance Factbook. Washington, DC: World Bank. 
Open Access This chapter is licensed under the terms of the Creative Commons Attribution 4.0 International License (http://creativecommons.org/licenses/by/4.0/), which permits use, sharing, adaptation, distribution and reproduction in any medium or format, as long as you give appropriate credit to the original author(s) and the source, provide a link to the Creative Commons license and indicate if changes were made.

The images or other third party material in this chapter are included in the chapter's Creative Commons license, unless indicated otherwise in a credit line to the material. If material is not included in the chapter's Creative Commons license and your intended use is not permitted by statutory regulation or exceeds the permitted use, you will need to obtain permission directly from the copyright holder. 